\title{
СОВРЕМЕНОТО МАКЕДОНСКО ОПШТЕСТВО ПОМЕЃУ ЛИБЕРАЛИЗМОТ И РЕБОЛШЕВИЗАЦИЈАТА
}

\section{Кратка содржина}

Во трудот се анализираат плимите и осеките на одделни либерални тендеции во македонското општество во периодот на сочијалистичка Југославија. Анализата е поставена во контекст на политичките слободи, слободата на творештвото и можностите за различни толкувања на тогаините опитествени состојби. Во тие рамки се посочуваат и одделни карактеристични примери од персонална природа преку кои се прекршувале тенденциите на болшевизмот и либерализмот во Република Македонија.

Клучни зборови: БОЛШЕВИЗАМ, ДОГМАТИЗАМ, ЛИБЕРАЛИЗАМ, СОЦРЕАЛИЗАМ, КОМУНИЗАМ, ДЕМОКРАТИЈА

Либерализмот и болшевизмот беа две паралелни појави кои го следеа развојот на современата македонска држава во рамките на југословенската федерација (1944-1991), со различен степен на доминација на едната или другата тенденција. Притоа, условно, либерализмот го означува стремежот кон демократија, идеолошка и политичка различитост, правото на избор на различни опции изразено низ барање реформи на системот и во владеачката партија. Наспроти овие вредности, болшевизмот како поим е употребен за ознака на догматизмот, униформноста, еднопартизмот, идеолошката и политичката монолитност чија основна карактеристика е постоењето на еден авторитарен центар и тендецијата за непроменливост на состојбите.

Во првите повоени години, во времето на зацврстувањето на комунистите на власт и доминацијата на болшевизмот, најголемиот број осудени и ликвидирани се третираат како остатоци на класните и граѓански политички структури, припадници на ВМРО и Ванчо Михајлов и империјалистички агенти ${ }^{1}$. По судирот на КПЈ со Информбирото претежно се гонат информбировците, а потоа следат про-

\footnotetext{
${ }^{1}$ Според Едвард Кардељ, „реакцијата“ во Југославија не се тепа „како некоја националнополитичка опозищија, туку како агентура на империјализмот“ во земјата, „како упориште и пипалка на странска шпиунска и диверзантска служба“. И затоа „се тепа безобзирно и физички се истребува“ (Архив Југославије (натаму АJ), 507, ЦК СКЈ IX/1,19/IV). Во пролетта 1945 година и Јосип Броз-Тито ќе признае дека тогаш лесно се губела главата и во Македонија, за понатаму да заклучи дека до крајот на годината народот веќе отрпнал, па никој не се плашел од смртна казна. На една од седниците на Политбирото на ЦК на КПЈ во април 1945 година Тито ќе соопшти дека „премногу луѓ се осудуваат на стрелање во Македонија“. (АЈ, 507, ЦК КПЈ 1945/339).
} 
гони за ѓиласовштина, ранковиќевци (етатистичко-бирократски сили), либерали, анархолиберали, националисти, техноменаџери, граѓанска десница итн. Со самото именување на „непријтелските“ сили во одделните историски фази може да се проникне и во променливите плими и осеки помеѓу ригидниот догматизам и либералните тенденции (реформаторството). Генерално гледано, и покрај присутните реформаторски обиди, ке биде евидентна супрематијата на партиското над државното право, на еднопартискиот систем над плурализмот, релативизацијата на човековите права и слободи, доминацијата на државниот интервенционизам над пазарните механизми во стопанството итн. Оделни реформски чекори за либерализација на системот преземани од врвот на партијата во праксата биле задушени од самата нејзина поставеност, монополска улога во општеството и пред сѐ од неприкосновениот култ на Јосип Броз - Тито.

Непосредно по формирањето на современата македонска држава - Демократска Федерална Македонија (2.8.1944), дел од нејзините творци беа носители на демократски или поинакви опции кои не се поклопуваа со политичките цели на Политбирото на ЦК на КПЈ. Во периодот од 1945 до 1953 година како време на најтврдиот сталинизам во Југославија и Македонија КПЈ/КПМ во спрега со органите за државна безбедност врши идеолошко-класна пресметка со реалните и наводни опоненти. Притоа, во недостиг на демократски традиции и под силна контрола на централните органи, македонското општество се покажало мошне ранливо и недоволно оспособено да се справи со таквата практика на владеачката еднопартиска гарнитура. Групата околу првиот претседател на Президиумот на АСНОМ, Методија Андонов - Ченто во период од неколку години, со различни идеолошко-политички дисквалификации беше тргната од политичката сцена ${ }^{2}$. Власта се концентрира во рацете на политичкиот секретар на ЦК на КПМ и претседател на првата Народна влада на Македонија - Лазар Колишевски кој во Македонија ги спроведува централизацијата на државата и болшевизацијата на партијата. Сферата на културата и творештвото, историографијата и другите општествени и хуманистички науки беа ставени под силна партиска контрола. Речиси сѐ до крајот на 80-те години на XX век толкувањата на најновата историја се движеа, главно, во рамките на квалификациите дадени во Политичкиот извештај на ЦК на КПМ поднесен на Првиот конгрес на КПМ (декември 1948). Притоа „приматот на политиката пред науката не постои само на идеолошко ниво, туку и фактичкото влијание на политичарите кои пишуваат историја и филозофија е поголемо отколку она на младата Клио која политизира“"3.

До средината на 50-те години југословенските интелектуалци кои не беа репресирани и изолирани по линија на „соработка со окупаторите и реакцијата“ или како информбировци, ангажирано го бранат фронтот на партијноста во култу-

\footnotetext{
${ }^{2}$ Виолета Ачкоска, Братството и единството 1944-1974 помеѓу хармонија и дисхармонија, Скопје 2003, 73-76.

${ }^{3}$ Стефан Требст, Бугарско-југословенската контраверза за Македонија 1967-1982, Скопје $1997,66$.
} 
рата и уметноста ${ }^{4}$, а толкувањата на општествените состојби главно се движат на нивото на ревидираниот марксизам-ленинизам. ${ }^{5}$ Ова време на револуционерниот занес од едната и „големиот страв“ од другата страна, на силно „стегање на ременот“ во име на блиската среќна иднина, подоцна во литературата ќе биде опишано како живеење помеѓу „херојското минато и уште посветлата иднина“6. Притоа, иако малку поспецифична, заради силната потреба од градење на национални вредности и институции, ситуацијата во однос на творештвото била слична и во НР Македонија. Се барало расчистување со буржоаското наследство и прифаќње на новиот поглед на свет, така што писателите, поетите, сликарите и другите творци обработувале мотиви за револуцијата, водачите, за силата на трудбениците итн. Еден од главните претставници на партискиот агит-проп во тоа време, писателот Владо Малевски ќе запише: „Понесени од миговите во кои живеевме непосредно по војната и задоени со соцреалистички норми за тоа што е и каква треба да биде новата сочреалистичка уметност (трансплантирани во нас уште во предвоените години од земјата на нашите комунистички мечти), сите ние, кој со повеќе кој со помалку успех, ја воспевавме револуцијата и човекот што таа го изобликувала со своите огнови, чекани и наковални..." “7 . И првиот роман на македонски јазик Село зад седумте јасени на Славко Јаневски ги изразува тие тендеции во литературата. Меѓу другото, Јаневски им сугерира на ликовните творци дека V Конгрес на КПЈ и I Конгрес на КПМ ги определиле најважните задачи кои стојат пред творештвото на нашата уметност - преку борбата со „аполитичноста“, „непријателските буржоаски влијанија“, „против идеалистичките разбирања и мистиката", поставувајќи апсолутна задача за партијност во културата и уметноста, за создавање вистинска уметност. ${ }^{8}$ Јаневски, инаку еден од најплодните македонски писатели, со децении се јавува како моќна еминенција која дава квалификации/дисквалификации за одредени творци не од аспект на естетските вредности на нивното творештво, туку од аспект на нивната партиско-политичка „подобност“9 .

${ }^{4}$ Во тој дух еден од водечките партиски идеолози до 1953 година, Милован Ѓ илас, вели дека „искуствата со остроумните, паметни интелектуалци, кои имаат смисол за агитационопропагандна работа, а не се до крај верни на Партијата - многу се жалосни" (Милован Ѓ илас, „Проблеми школства у борби за социјализам у нашој земљи, Реферат на Трећем пленуму ЦК СКЈ“, Седниче ЦК СКЈ 1948-1952, Београд 1985, 288-310).

${ }^{5}$ Dragan Marković, Josip Broz Tito i Goli Otok, "Beseda", Beograd 1990, 64.

${ }^{6}$ Branko Petranović, Istorija Jugoslavije 1918-1988, Beograd 1989, 28.

7 Владо Малевски, „Искажувања за педесеттите години во културата“, Денес 1953-1983, Скопје 1983, 11.

${ }^{8}$ Славко Јаневски, „Четврта изложба на уметниците во Македонија“, Нов ден, 3, 1949.

9 Јаневски кого службите го воделе под шифрата „Славјан“, меѓу другото, дава информации за политичко-партиските ставови и однесување на: Радован Павловски, Венко Марковски, Михаил Ренџов, Гане Тодоровски, Димитар Јоновски, Петре Андреевски, Душко Наневски, Живко Чинго, Ристо Шишков итн. (Предраг Димитровски, Лустрачијата во Македонија, Скопје 2015, 151-163; Александар Русјаков, „Академизам“, Нова Македонија, 13. 03.2016; Истиот, „Пионери, пионерки, кодоши и партиски вверки“, Нова Македонија, 2.07. 2013; www.kvf.org.mk/index/mk/registar, реш. Бp. 07-10391/1 од 26.06.2013, 14.3.2016). 
На планот на идеолошките чистки во борбата против Сталин (1948-1953), Политбирото на ЦК на КПЈ, во кое се наоѓаа кадри образувани во болшевичките црвени универзитети или личности кои ја прифатија сталиновата теорија за засилување на „класната борба“ во социјализмот, ги примени најсталинистичките методи за „општествено превоспитување“, проследено со бројни ликвидации на реални опоненти и измислени непријатели. Голи Оток е парадигмата на тоа монструозно газење врз човечкото достоинство, иако, според официјалните толкувања, сето тоа било спроведено заради одбрана на државата од внатрешните непријатели. Ако за внатрешни непријатели во НР Македонија беа прогласени основоположници на државата, учесници во НОБ, македонски дејци, припадници на ВМРО (Обединета), шпански борци, чесни комунисти и бројни други тогаш за обичните граѓани настапува трауматско време на страв за сопствениот живот и општа клима на несигурност. ${ }^{10}$

За среќ, набрзо следи отрезнување и прифаќње на гледиштето дека револуцијата не значи истребување на луѓе, туку промена на правилата. Така, уште пред смртта на Сталин (март 1953) и нормализацијата на односите со СССР и источните земји, врвните југословенски идеолози бараат нови излезни патишта заради надминување на сталинистичката практика и се навраќаат на извориштето на марксизмот. Шестиот конгрес на КПЈ (1952) декларативно востановува нова улога на партијата. Наместо раководна, таа да има водечка идејно-политичка и насочувачка улога, при што го променува името во Сојуз на комунистите на Југославија $(\mathrm{CKJ})$. Истовремено највисокиот партиски форум дава зелено светло за развој на работничкото самоуправување, уставно инаугурирано во 1953 година.

Општествено-политичките промени ке најдат одраз и на планот на културата и уметноста. Станува видливо напуштањето на „идентификацијата меѓу доживувањата на единката и доживувањата на колективот“ (поврзани со „полетот на југословенските народи“, „со обновата и изградбата“), а колективните чувства и доживувања им отстапуваат место на индивидуалните. ${ }^{11}$ Тоа значело бунт против униформноста на поетската инспирација и почеток на ослободувањето на поезијата од црно-белите шеми на соцреализмот, при што следи соблекување на болшевичкото руво и во другите творечки сфери. Се појавува групата „Денес“ (1953) во рамките на која македонските ликовни творци отвораат поширок процес на барање автентични и помодерни изрази на ликовното творештво. Се засилуваат дебатите за интимната лирика во поезијата, се јавуваат нови теми во литературата.

${ }^{10}$ По линија на ИБ беа репресирани: Панко Брашнаров, Петре Пирузе-Мајски, Владимир Полежиноски, Кирил Петрушев, Генадиј Илиев Лешко, Лазар Соколов, Павел Шатев, Трајко Мишковски, Васил Калајџиски, Богоја и Јонче Фотев и многу други (Виолета Ачкоска, Никола Жежов, Репресијата и репресираните во најновата македонска историја, Скопје 2007, 218-283).

11 Збирките За радоста и маката (1950) и Слеј се со тишината (1952) на Ацо Шопов иницирале расправи околу прашањето на интимната лирика. (Атанас Вангелов, „Ацо Шопов (1923-1982)“, Литературен збор, бр. 3, Скопје 1983, 3). 
Некогашниот голем сталинов идолопоклоник, Милован Ѓлас (19111995), со статиите објавени во весникот „Борба“ (октомври 1953 - јануари 1954 година) го крева гласот против состојбата на „скаменети партиски мозоци“ и догматизирана идеолошка свест и бара обновување на повеќепартискиот систем. Гилас беше осуден како носител на анархо-либералистички тенденции кои добија и свое именување како ѓ гиласовштина. ${ }^{12}$ Македонските комунисти во текот на 1954/55 година, водат упорна борба против ,ѓиласовштината“ во сопствените редови. Со оглед на нивната ниска образовна структура и идејна свест, малкумина ја разбирале суштината на она за кое се залагал Ѓ илас, но упорно ја спроведувале официјалната „партиска линија“. Тие ги осудуваат „непријателските ставови” на Ѓилас кој наводно се приклонил кон империјалистичките непријатели и го загрозил монолитното единство на партијата. ${ }^{13}$

Набрзо по затворањето на Гилас, се јавува Венко Марковски со неговиот труд Современи парадокси (1955) каде ја соголува дикататурата во годините на судирот со ИБ и апсолутната власт на Јосип Броз. Марковски бил осуден и упатен во 1956 година на петгодишно „општествено превоспитување” во логорот Голи Оток. ${ }^{14}$ Истовремено, со него биле осудени композиторот Кирил Македонски (18 месеци строг затвор) и писателот Душко Наневски (1 година строг затвор) со обвинување дека го дистрибуирале трудот Современи парадокси. Кирил Македонски, авторот на првата македонска опера „Гоце”, ${ }^{15}$ како и Душко Наневски ке имаат долгорочни последици и ќе бидат предмет на постојана полициска обработка. Наневски дури ќе биде доведен до работ на тешка психолошка траума. ${ }^{16}$

И покрај честата променливост на општествена клима во однос на либерализацијата на политичките состојби и творечката мисла, надминувањето на соцреалистичките вредности и на догматизмот не можело да биде сопрено. Според Слободан Мицковиќ, „во тоа време Мајаковски и Есенин се веќе заборавени. Се

12 Мијалко Тодоровиќ, „Можда је могло и другачије бити“, Зб. Милован Ѓлас, Београд 1996, 43-51.

13 Јосип Броз - Тито, „Говор на Трећем (ванредном) пленуму ЦК СКЈ“, Комунист, 1-2/1954, $3-12$.

14 Виолета Ачкоска, „Историски и современи македонски парадокси - случајот на Венко Марковски“, Годищен зборник на Филозофскиот факултет, Скопје 2009, 233-250.

${ }^{15}$ Во 1972 година и покрај видниот музички опус, Кирил Македонски по четврти пат не беше примен во Друштвото на композиторите („Извештај на РСВР за разговори и контакти на Ѓорги Ордев, 20.3.1972“, Демнеечки дух, Тајното поличиско досие на политичкиот затвореник, суден за Македонија, Ѓрѓ́ Дочев Банев, Редакција и коментари В. Ачкоска, Скопje 2012, 83).

${ }^{16}$ Душко Наневски во периодот 1949 -1951 година бил одведен на „општествено превоспитување“ на Голи Оток, како студент на Високата новинарска дипломатска школа во Белград заради „учество во илегална ИБ-група“ и заради растурање на летоци. (РСВР-СРМСДБ, лично досие бр. 1-04565/8, 29.8.1981). Тој ќе биде предмет на постојани иследувања, а особено ќе биде дискредитиран од страна на „Славјан“. 
открива Лорка, доаѓа Пастернак. Се насетува Сен Џон Перс, се задава сенката на Елиот, се чуствува аромата на источната поезија““17.

Силината и бројот на политичките прогони веќе се сведува на далеку помал број. Тито започнува пробив на меѓународната сцена, промовирајќ ја политиката на мирољубива коегзистенција и неврзување. Во тој контекст, од едната страна, режимот безалтернативно го чува политичкиот монопол на СКЈ, но од другата, заради меѓународниот углед, мора да ја легитимира Југославија како земја на демократски самоуправен социјализам која го отфрлила сталинистичкото наследство и бруталните методи на пресметки со политичките противници.

По Седмиот конгрес на СКJ (1958) и особено во почетокот на 60-те години започнува постепена рехабилитација на жртвите од времето на Информбирото, при што се врши повторен прием на дел од истите за кои Партијата утврдувала дека се „превоспитани“'18. Нашироко се промовира мислата за поголема слобода на творештвото која наводно ќе одговара на југословенскиот пат на изградбата на социјализмот. Тоа е време кога заради критиките на новата Програма кои доаѓале од Исток, партијата морала да „пушта“ слобода на творештвото, но, истовремено, барала творците и интелигенцијата „да застанат во одбрана на програмските ставови на CKJ““, односно не се напуштала старата шема на славење на партијата. ${ }^{19}$

Во таквата клима се забележливи повеќе национални манифестации на дел од новата генерација творечка македонска интелигенција. Оваа интелигенција била на позициите на изградбата на југословенскиот социјализам, што значи дека немало основи за нејзина идеолошка дисквалификација, но таа истовремено поставувала барања кои сосема не се вклопувале во официјалната југословенска надворешна политика. Во овој контекст се залагала за почитување на правата на Македонците во соседните држави, особено во Грција. ${ }^{20}$

Плашејќи се од преголема „доза на македонски национални чуства“ и заради поголема контрола врз историјата и историчарите, македонското партиско раководство во почетокот на 1959 година носи одлука за припојување на Историскиот архив при ЦК на СКМ во составот на Институтот за национална историја. Истовремено при ЦК на СКМ била формирана Комисија за историјата на СКЈ при ЦК на СКМ која добила задача „да организира пишување и да ги контролира текстовите што се однесуваат на историјата на работничкото движење, СКЈ и НОБ, за

${ }^{17}$ Слободан Мицковиќ, „Три мига на македонските литературни генерации“, Разгледи, 9/ 1964, Скопје, 827.

${ }^{18}$ Државен архив на Република Македонија (натаму ДАРМ), п. о. Велес, ф: Околиски комитет - Т. Велес, к-13, Информација за држењето и работата со лица кој се биле по ИБ затворани, судени, повикувани и др., 1962/63.

${ }^{19}$ Миомир Гаталовиќ, „Измеѓу идеологије и стварности, Социјалистички концепт културне политике Комунистичке партије Југославије (Савеза комуниста Југославије) 1945-1960“, Историја 20 века, 1/2009, 53-54.

${ }^{20}$ ДАРМ, ф: ЦК СКМ, к-69, а.е. 33, Анализа на политичките појави во врска со македонското национално прашање, Скопје, 17.11.1958. 
енциклопедијата на Југославија“. ${ }^{21}$ Нагласокот на проучување на македонската историја е ставен врз НОБ и „револуцијата“ (како термин додаден по 50-те години), така што на оваа тематика се создава прекубројна историографска продукција, десеткратно повеќе во однос на сите други периоди од македонската историја. И сето тоа, се разбира, ќе подлежи на педантна „партиска цензура““22.

Во исто време, во рамките на Универзитетот „Кирил и Методиј“, дел од македонската интелигенција реагира против засиленото влијание на српскиот јазик, како при печатењето на одделни скрипти на српски јазик од професорите на скопскиот универзитет дојдени однадвор, така и против држење предавања на српски јазик. Преземајќ ја врз себе улогата на главен судија на овие „националистички испади“, партискиот лидер Колишевски се обраќа пред комунистите на Универзитетот на изборната конференција на СКМ, одржана на 9-10 јануари 1960 година, „со изразито унитаристички ставови и користење на интернационалистичка терминологија“, при што и без да сака, ги потврдувал „бугарските критики во однос на србизацијата на македонскиот јазик“23.

Во рамките на „дозволените слободи“ на творците во Југославија, одделни партиски бирократи во републиката доживеале своевиден шок со појавата на првите раскази на писателот Живко Чинго (1935-1987) во 1956 година, а во 1961 година и на збирката „Пасквелија“棌 во која жестоко се критикуваат догматските толкувања на „револуцијата“ и „комунизмот“ и со особена иронија се опишува суровоста и примитивизмот на носителите на „народната“

Во 1963 година, кога насекаде се зборува за југословенскиот самоуправен социјализам, кога се случуваа силни интелектуални пробиви на планот на литературата и уметноста, за вербален деликт во логорот Голи Оток престојува големиот македонски сликар Родољуб Анастасов. Имено, по говорот на претседателот Тито во Сплит во кој „меѓу другото укажал и на некои девијации во уметноста кај нас“, Анастасов коментирал: „Што се меша Тито во уметноста, тој е неук за тоа, нека

${ }^{21}$ ДАРМ, ф. ЦК СКМ, к-66, а.е. 82, Записник бр. 1 од седница на Извршниот комитет на ЦК СКМ, 19.2.1959.

22 За жал, интегрална историја на КПМ/СКМ никогаш не е напишана заради прикривање на историските факти околу вистинското делување во текот на НОБ, но и потоа, на одделни личности од врвот на партијата.

${ }^{23}$ Крсте Црвенковски, Славко Милосавлевски, Нашиот поглед за времето на Колишевски, Скопје 1996, 237-247.

${ }^{24}$ Димитар Митрев, „Случајот Чинго“, Современост, 1966, бр. 4, 334-348.

${ }^{25}$ Малтретиран да биде кодош заради компромитација на неговото дело, изложен на следење, чести повици во полицијата, при што од полициски претреси и закани не беа поштедени ни неговите родители, Чинго во голема мера беше почитуван и заштитуван од врвни југословенски писатели и интелектуалци кои со воодушевување ја прифатија таа нова проза на изразито надарениот македонски писател. Во одделни периоди беше невработен и со одземена патна исправа, изложен на закани по неговиот и животот на неговото семејство (Виолета Ачкоска, „Живко Чинго за револуцијата и селото“. ХХІХ Меѓународен семинар за македонски јазик, литература и култура, Универзитет “Свети Кирил и Методиј“, Скопје, 1997, 95-110; Лични сеќавања на авторот на овој прилог). 
си ја гледа политиката и својата работа. За уметноста има образовани луѓе кои ќе се грижат “26. Заради овој исказ и заради неговите разговори со другарите за време на отслужувањето на воениот рок (ставот дека Југославија ќе се распадне по смртта на Тито итн.) одлежал две години и шест месеци на Голи Оток. ${ }^{27}$ Престојот во логорот се одразил и на творечкиот опус на Анастасов, а особено е впечатлив циклусот Човекот и просторот.

Во летото 1963 година се случува персоналната смена на врвот на СКМ. На местото на Лазар Колишевски, раководната функција ја презема Крсте Црвенковски. Набрзо следи и одржувањето на Четвртиот или Брионскиот пленум на ЦК на СKJ (1 јули 1966 година) на кој од политичката сцена беше тргнат еден од најдоследните титови соработници - Александар Ранковиќ, како и Светислав Стефановиќ, сојузен секретар за внатрешни работи. ${ }^{28}$ Ранковиќ беше прогласен за носител на централистичко-бирократските деформации и унитаристички тенденции во југословенското општество, кое во текот на 1965 година доживува тешка стопанска криза и ќе мора да се откаже од т.н. Стопанска реформа.

Во сите републики се расчистува со „деформациите“ констатирани на Брионскиот пленум, така што, Извршниот совет на Собранието на СРМ, на седницата од 12.8.1966 година оценува дека е потребно непосредно да се согледа состојбата во Републичкиот секретаријат за внатрешни работи, посебно во органите за државна безбедност во СРМ. ${ }^{29}$ Во тие рамки е формирана Комисија на чело со Веселинска Малинска која, меѓу другото, востановила дека под различен вид евиденција во републиката, во службите за државна безбедност, во актуелниот момент се наоѓале 96.531 лице, на кои им биле отварани лични досијеа. До мај 1965 година бројот на по таков начин евидентирани лица изнесувал 136.682. Со личните досијеа бил опфатен широк круг на граѓани - општествено-политички, јавни и културни работници, особено луѓе од редот на универзитетските наставници. Голем дел од внесуваните извештаи воопшто немале карактер на безбедносен материјал туку се однесувале на меѓусебните односи во работната организација, во работата на самоуправните органи, во личните и интимни работи на луѓето итн.

\footnotetext{
${ }^{26}$ Републички секретаријат за внатрешни работи - СРМ, Лично досије на Родољуб Анастасов бр. 3137, Записник од сослушување на сведок, 14.5.1963.

${ }^{27}$ Според исказите на Анастасов најтешка на Голи Оток за него била несоницата. Со недели и месеци не спиел и бил „на штрек“ заради некое убиство кое се случило при спиење во логорската барака. Всушност „неспиењето“ било еден од најсуптилните методи на психолошко измачување на Голи Оток, за што творците на ова мачилиште побарале мислење од психијатар.

${ }^{28}$ ДАРМ, ф: ЦК КПМ/СКМ, к-150, а.е. 6, Белешки од 29. седница на ИК ЦК СКМ, 23.6. 1966.

${ }^{29}$ Комисијата на 20.9.1966 поднесла извештај до Собранието на СРМ. Се констатира дека македонските служби не учествувале во „заговорот Ранковиќ-Стефановик“", но дека „бирократско централистичката поставеност и вертикалната хиерархиска подреденост на државната безбедност“ делувале врз нејзиното обезличување и отуѓување од општеството, при што биле присутни повеќе деформации и бројни злоупотреби (ДАРМ, ф: 158, к-157, а.е. 9, 456-466).
} 
Прислушувањето на телефонските разговори било широко користено, како и озвучувањето на простории и отворањето на поштата на одделни лица. Нагласено внимание било посветувано на појавите и мислењата меѓу интелигенцијата. ${ }^{30}$

Кон средината на 60-те години (по Осмиот конгрес на КПЈ - 1964), како резултат на продлабочувањето на економскиот јаз помеѓу северот и југот, на преден план повторно избива едно од најчуствителните прашања во федерацијата националното прашање. Забележливо е дека СКЈ повеќе бил свртен кон „критика на негативните појави во меѓунационалните односи“, а помалку кон толкувања на тие појави и објаснување на тоа зошто повторно морале да се актуелизираат меѓунационалните односи. Некои републики бараат располагање со сопствените девизи, формирање посебна армија итн. ${ }^{31}$ Особено внимание се посветувало на изучувањето на историјата како клучен фактор во создавањето на одредена општествена и историска свест, под строга контрола на партијата. Меѓу другото, се инсистира на рамномерно изучување на историите на југословенските народи, како еден од патиштата за создавање на заедничка југословенска свест наспроти сѐ посилно изразениот национален „сепаратизам““. ${ }^{32}$

При крајот на 60-тите години, на дневен ред се поставува прашањето за рамноправноста на употреба на јазиците како едно од најчуствителните прашања. Започнува жестока српско-хрватска дебата околу прашањето на јазикот, која предизвика реакции и во Македонија. Притоа една група македонски интелектуалци, повеќето писатели, ќе се заложи за поадекватна застапеност на македонскиот јазик во секојдневното комуницирање. ${ }^{33}$ Во таквата атмосфера, Крсте Црвенковски како водечки македонски кадар, енергично ги застапува македонските интереси. Во голем дел, благодарејќи на таквите негови напори, во 1967 година се формира Македонската академија на науките и уметностите (МАНУ) и се прогласува авто-

${ }^{30}$ Службите оделе и во такви крајности, што некаде директно, а некаде индиректно се вплеткувале во кадровски прашања, користејќ најразлични методи и уцени. Констатирана е практиката на монтирање „предмети“ и добивање признанија под психичка и физичка тортура на личностите и дека „системот и методот на работа на Службата за внатрешна безбедност претставувале најфлагрантни повреди на уставноста и законитоста, тотална контрола над општеството, узурпирање на уставните и законските права на граѓаните, на работните организации и органите на самоуправување“. (ДАРМ, ф: 158, к-157, а.е. 9, 456466).

${ }^{31}$ Arhiv Republike Slovenije, f: CK ZKS, št.195, Neki problemi međurepubličkih i međunacionalnih odnosa, Beograd, CK SK Srbije, oktobar 1966.

${ }^{32}$ Во една анализа од 1968 година е констатирано дека македонските ученици во средното образование ја учат историјата од хрватски или српски учебници каде над $50 \%$ била обработена историјата на хрватскиот односно српскиот народ, а во другиот дел се дава преглед на историјата на другите народи и народности во СФРЈ (ДАРМ, ф: ЦК СКМ, Комисија за односите меѓу републиките, нациите и народностите, к-157, а.е. 39, Некои актуелни прашања во врска со поставеноста на историјата на македонскиот народ и другите народи на Југославија во училиштата од II степен, мај 1968).

33 Јован Филип, Подводни гребени на политиката, разговори со Крсте Црвенковски, Скопje 1993, 97-98. 
кефалност на Македонската православна црква (МПЦ), две значајни национални институции кои придонесоа за уште поголема афирмација на македонската нација.

Во почетокот ортодоксен комунист, Црвенковски постепено станува носител на пролиберални тенденции и застапник на идејата за демократизација на општеството и партијата. Токму затоа, набрзо и тој ќе ја сподели судбината со групата на југословенската партиската интелектуална елита - Трипало, Никезиќ, Перовиќ, Кафчич. Во кус период по симнувањето на Ранковиќ, оваа група на прогресивни партиски кадри е миленик на Јосип Броз. Но, за жал, тој набрзо ќе ја напушти намерата за справување со политиката на цврстата рака и централистичкобирократските тендеции. Некаде од 1968 година тивко, а поинтензивно по 1971 година, исплашен од многуте настани (студентски немири, мас-покретот, демонстрации на албанската народност), но и од лавината на либерализмот во редовите на СКJ, која можеше да го сруши неговиот примат и монополската владеачка улога на партијата, Броз се враќа во сигурноста на „старата гарда“ и болшевизмот.

Во рамките на процесите за реформирање на СКЈ и на нејзината улога во општеството, спаѓ и македонскиот обид од 1971/73 година. Во таа „либерална“ група во Македонија, највидни беа: К'амуран Тахир, Димитар Мирчев, Томислав Чокревски, Славко Милосавлевски, Милан Недков, Љупчо Арнаудовски и други ${ }^{34}$ Се работело за судар на две тенденции во СКМ, каде видна улога играле и одредените политички личности: првата, која останувала на тврдата линија за status quo (Колишевски), и втората, која се залагала за длабоки и поструктурални промени (Црвенковски), плурализам, право на критика, право на штрајк и други мерки за демократизација на општеството. ${ }^{35}$ Крсте Црвенковски ке биде идеолошки и политички дисквалификуван на 36-та седница на ЦК СКМ (18.1.1973), именувана како „пресвртница во пресметката со либерализмот и национализмот во Македонија". Набрзо е одржана 37-та седница (4.2.1973) во духот на целосна победа на догматската струја (Ангел Чемерски, Васка Дуганова, Мито Мицајков идр.). Јосип Броз не покажал изразена заитересираност за судирот во СКМ бидејќи со него не била директно загрозена неговата положба. ${ }^{36}$

Со ударот во Хрватска и Србија, во поблага форма во Словенија и Македонија, „завршен е дваесетгодишниот период на демократизација на револуционерната диктатура. Потоа настапува десетгодишен период на партиска диктатура. Политичкиот живот ќе биде сосема умртвен". ${ }^{37}$ Всушност тоа беше чин не само на зацвсрстувањето на власта, туку и на реболшевизација на партијата, која ја напушта функцијата на насочувачка улога и повторно врз себе ја превзема улогата на команден центар.

\footnotetext{
${ }^{34}$ Крсте Црвенковски, Мирче Томовски, Заробена вистина, Скопје, 2003, 628-635; Јован Филип, исто, 163-164, 173-175.

35 Крсте Црвенковски, Славко Милосавлевски, Нашиот поглед за времето на Колишевски., 135-145.

${ }^{36}$ Božo Repe, ,Liberalizem“ v Sloveniji, „Borec“, Ljubljana 1992, 238.

${ }^{37}$ Dušan Bilanđić, Hrvatska moderna povijest, Zagreb, 1999, 665.
} 
Во расчистувањето со либерализмот, заради внатрешната кохезија и надворешниот углед, Тито јавно не сакал да демонстрира политичко насилство иако тоа постоело закамуфлирано. ${ }^{38}$ Во Македонија била елиминирана целата либерална елита. Според Димитар Мирчев, околу 2000 луѓе, главно интелектуалци, директори, уметници, новинари итн. биле или остранети (пензионирани, сменети од функции), елиминирани од јавниот живот, а врз сите нив се засилила контролата и притисокот. ${ }^{39}$ На македонската политичка сцена повторно ќе стапи старата догматска структура на чело со Колишевски.

Јосип Броз кој во 1974 година беше уставно потврден како доживотен претседател, се врати во сенката на сигурноста на оние кои му беа до крај послушни и кои со свеста сѐ уште живееја во военото и поствоеното време. Со стари догматски погледи за улогата на државата, власта, политиката, творештвото, тие беа сосема неподобни за новите историски предизвици на европските седумдесетти и осумдесетти години. Болшевизмот, кој требаше да биде потиснат за сметка на либерализмот доживеа ренесанса. Македонското општество се реболшевизира. Процесот на реболшевизација особено се засили по 1980 година, по смрта на Јосип Броз Тито. Веќе изградениот болшевичко-сталинистички тип на партија, односно СКЈ во практиката толку цврсто го држи монополот на власта така што не можела ни најмалку да отстапува од тој монопол и да ја ослабува својата раководна улога. Со оглед на фактот што дотогаш составен дел и центар на таквиот монопол беше Титовиот неприкосновен авторитет и неговата автократска положба во системот, по неговата смрт, водечката партиска елита го издигна слоганот „И по Тито - Тито“. На тој начин таа прогласи дека владее во името на Тито како апсолутен (и единствен) продолжувач на неговото дело. Тоа значеше потиснување на сите натамошни обиди за демократизација и либерализација на системот.

Како карактеристичен пример за прогон на јавните личности и интелектуалци ќе го посочиме досијето „Табакерата“ водено за македонски актер Ристо Шишков (1940-1986). Етикетиран како „македонски националист“, тој со години беше ставен под посебен режим на присмотра и психолошка разработка, а потоа суден за вербален деликт, во периодот од пролетта 1979 до ноември 1981 година. ${ }^{40}$ Професорот Ѓ орги Марјановиќ, покренувајќи јавна дебата против оваа антидемократска одредба беше изложен на различни дисквалификации. Бројни македонски творци паднаа во немилост, беа заплашувани, се полнеа илјадници доси-

\footnotetext{
${ }^{38}$ Напротив, Тито создавал „впечаток, дури и атмосфера на другарско разидување и впечаток на човек кој простува, па дури и се чуди зошто оставката се поднесувала толку набрзина“. Но, како што покажувало времето „со сменетите се разидувал засекогаш, и наспроти долгата соработка, ретко примал некого назад по симнувањето...“ (Тодор Куљиќ, Tuто, coчиолоико-историска студија, друго, допуњено издање, Зрењанин, 2005, 169-170).

${ }^{39}$ Димитар Мирчев, Европеизам, либерализам, македонизам, Скопје 2015, 125-128.

${ }^{40}$ Тоа беше време кога наградите го заобиколуваа Ристо Шишков. Така, за маестралната улога на Никодин, во Кенгурскиот скок на Чинго, на театарските игри во Нови Сад („Стеријино позорје“), македонскиот актер беше најгрубо заобилколен (Гоце Ристовски, Шищков, Скопје 1999, 144, 158).
} 
jea. ${ }^{41}$ Различните скромни обиди за преиспитување на титовото владеење и време беа попречувани низ различни механизми, иако на планот на уметничкото творештво тоа не можеше да биде запрено. ${ }^{42}$ Меѓу другото, во септември 1984 година, беше донесен и Закон за заштита на името и делото на Јосип Броз - Тито. ${ }^{43}$

Во атмосфера на притисок и репресија врз творците, особено е трагичен случајот на македонскиот поет Јонче Котески, следен во приодот 1960-1990, а осуден и затворен во септември 1985 година, за наводна непријателска дејност. Во јули 1987 година, по околу две години затвор, Котески е пуштен на слобода. За неговото ослободување најмногу бил заслужен тогашниот потпретседател на светскиот ПЕН-центар и хрватскиот ПЕН-клуб, Предраг Матвеевиќ, кој организирал петиција со светски познати писатели до највисокото македонско раководство $^{44}$. Отсуството на реакција од страна на македонските интелектуалци зборува за климата во општеството - сервилност или исплашеност од режимот.

Во прогонот на нелојалните и сомнителни интелектуални умови беше измислена и нова идеолошка дисквалификација, т.н. граѓанска десница, во чии рамки за еден од водечките идеолози беше посочуван проф. д-р Ферид Мухиќ. Посебно интересен, денес веќе од историографски аспект, е т.н. „Вевчански случај“ кој можеме да го оцениме како бунт против бирократските деформации и привилегии на функционерите од врвот на СКМ. Во периодот од 26 мај до 7 август 1987 година, селото Вевчани буквално беше опседнато од полиција, притисоци и тортура, при што полициските сили употребија насилство и врз вевчанските жени. Случувањата одекнаа низ цела Југославија. Врвни уметници, културни работници, интелектуалци и демократската јавност застана во одбрана на вевчанци, против полициското насилство и кршењето на граѓанските права ${ }^{45}$.

${ }^{41}$ Шишков за кој беше молкум забрането да настапува, доби улога (Веселникот) во драмата на Чинго „Маквејските празници“ на сцената на МНТ, чија премиера се одржа во февруари 1983 година. За оваа драма Чинго беше повеќ пати повикуван на разговори од партискополициски функционери заради „проблематичниот“ текст, но и заради ангажманот на Ристо Шишков. Драмата набрзо испари од сцената и „никој не смееше да праша за забраната“. (Бранко Ставрев, „Доброволни будали“, Пулс, 15.8.1991, 19).

${ }^{42}$ Во 1971 година појавата на Големата вода на Чинго како антидогматска и антисталинистичка проза беше доживена како своевиден шок кај властите. Табу-темата за Информбирото и Голи Оток ќе биде повторно отворена од страна на писателите (Исаковиќ со Трен I и Трен II) и филмските работници во СФРЈ. Историчарите беа под силна контрола и доцнеа зад писателите во обработката на табу-темите. Во СРМ во 1986 година ке биде прикажан филмот Среќна Нова 49 на режисерот Столе Попов на темата на Информбирото.

43 Закон за употреба на името и ликот на Јосип Броз - Тито, Службен лист СФРЈ, 28, септември 1984, бр. 51, год. XV, 1179-1181.

44 Јасна Котеска, Комунистичка интима, Скопје 2008, 38-45.

45 Вевчанщи еднодушно го дигнаа гласот против бесправното одземање на поголемо количество вода од договореното од Вевчанските извори за потребите на вилската населба „Елен камен“ каде функционерите градеа свои викендички. (Крсто Шканата, Хвала на слободи, Београд 1988, документарен филм посветен на Вевчанскиот случај). 
До крајот на 1980-те години, македонското општество тешко се ослободуваше од плаштот на догматската свест кое се покажа како макотрпен процес и во рамките на плуралистичка Република Македонија по 1991 година. Отпорите против отворањето на табу-темите во историјата, против расчистувањето со црните дамки на комунистичкото минато и препреките околу спроведувањето на лустрацијата се дел од болшевистичката свест и минато во кои се најде заплеткано македонското општество и од кои тешко се ослободува. Либералната демократија сигурно не е „крајот на историјата“, туку таа е само една од можните опции за достигнување повисок степен на демократија. 


\section{Литература}

\section{Извори:}

Архив Југославије, 507, ЦК СКЈ IX/1,19/IV.

Архив Југославије, 507, ЦК КПЈ 1945/339.

Arhiv Republike Slovenije, f: CK ZKS, št.195, Neki problemi međurepubličkih i međunacionalnih odnosa, Beograd, CK SK Srbije, oktobar 1966.

Државен архив на Република Македонија (натаму ДАРМ), п. о. Велес, ф: Околиски комитет - Т. Велес, к-13, Информација за држењето и работата со лица кој се биле по ИБ затворани, судени, повикувани и др., 1962/63.

ДАРМ, ф: ЦК СКМ, к-69, а.е. 33, Анализа на политичките појави во врска со македонското национално прашање, Скопје, 17.11.1958.

ДАРМ, ф. ЦК СКМ, к-66, а.е. 82, Записник бр. 1 од седница на Извршниот комитет на ЦК СКМ, 19.2.1959.

ДАРМ, ф: ЦК КПМ/СКМ, к-150, а.е. 6, Белешки од 29. седница на ИК ЦК СКМ, 23.6.1966.

ДАРМ, ф: 158, к- 157 , а.е. 9, 456-466

ДАРМ, ф: ЦК СКМ, Комисија за односите меѓу републиките, нациите и народностите, к-157, а.е. 39 , Некои актуелни прашања во врска со поставеноста на историјата на македонскиот народ и другите народи на Југославија во училиштата од II степен, мај 1968.

Републички секретаријат за внатрешни работи - СРМ, Лично досије на Родољуб Анастасов бр. 3137.

Републички секретаријат за внатрешни работи - СРМ, Лично досије на Душко Наневски бр. 1-04565/8.

Шканата Крсто, Хвала на слободи, Београд 1988, документарен филм.

www.kvf.org.mk/index/mk/registar, реш. Бр. 07-10391/1 од 26.06.2013, 14.3.2016.

\section{Литература:}

Ачкоска Виолета, Братството и единството 1944-1974 помеѓу хармонија и дисхармонија, Скопје 2003.

Ачкоска Виолета, „Историски и современи македонски парадокси - случајот на Венко Марковски“, Годишен зборник на Филозофскиот факултет, Скопje 2009

Ачкоска Виолета, „Живко Чинго за револуцијата и селото“. ХХІХ Меѓународен семинар за македонски јазик, литература и култура, Универзитет "Свети Кирил и Методиј “, Скопје, 1997.

Ачкоска Виолета, Никола Жежов, Репресијата и репресираните во најновата македонска историја, Скопје 2007.

Bilanđić Dušan, Hrvatska moderna povijest, Zagreb, 1999. 
Броз Јосип - Тито, „Говор на Трећем (ванредном) пленуму ЦК СКЈ“, Комунист, $1-2 / 1954$

Вангелов Атанас, „Ацо Шопов (1923-1982)“, Литературен збор, бр. 3, Скопје 1983.

Гаталовиќ Миомир, „Измеѓу идеологије и стварности, Социјалистички концепт културне политике Комунистичке партије Југославије (Савеза комуниста Југославије) 1945-1960“, Историја 20 века, 1/2009

Демнеечки дух, Тајното поличиско досие на политичкиот затвореник, суден за Македонија, Горѓ Дочев Банев, Редакција и коментари В. Ачкоска, Скопje 2012.

Димитровски Предраг, Лустрачијата во Македонија, Скопје 2015

Гилас Милован, „Проблеми школства у борби за социјализам у нашој земљи, Реферат на Трећем пленуму ЦК СКЈ“, Седнище ЦК СКJ 1948-1952, Београд 1985.

Јаневски Славко, „Четврта изложба на уметниците во Македонија“, Нов ден, 3, 1949.

Котеска Јасна, Комунистичка интима, Скопје 2008

Куљиќ Тодор, Тито, сочиолошко-историска студија, (друго, допуњено издање), Зрењанин, 2005

Малевски Владо, „Искажувања за педесеттите години во културата“, Денес 19531983, Скопје 1983.

Marković Dragan, Josip Broz Tito i Goli Otok, "Beseda", Beograd 1990.

Мирчев Димитар, Европеизам, либерализам, македонизам, Скопје 2015

Митрев Димитар, „Случајот Чинго“, Современост, 1966, бр. 4.

Мицковиќ Слободан, „Три мига на македонските литературни генерации“, Разгле$\partial u, 9 / 1964$, Скопје

Petranović Branko, Istorija Jugoslavije 1918-1988, Beograd 1989.

Repe Božo, "Liberalizem" v Sloveniji, "Borec", Ljubljana 1992

Ристовски Гоце, Шишков, Скопје 1999.

Русјаков Александар, „Академизам“, Нова Македонија, 13.3.2016.

Русјаков Александар, „Пионери, пионерки, кодоши и партиски зверки“, Нова Македонија, 2.7.2013.

Ставрев Бранко, „Доброволни будали“, Пулс, 15.8.1991.

Тодоровиќ Мијалко, „Можда је могло и другачије бити“, Зб. Милован Ѓ Глас, Београд 1996

Требст Стефан, Бугарско-југословенската контраверза за Македонија 1967-1982, Скопје 1997.

Филип Јован, Подводни гребени на политиката, разговори со Крсте Црвенковски, Скопје 1993. 
Црвенковски Крсте, Милосавлевски Славко, Нашиот поглед за времето на Колишевски, Скопје 1996.

Црвенковски Крсте, Мирче Томовски, Заробена вистина, Скопје, 2003. 
Violeta ACHKOSKA

\section{MACEDONIAN MODERN SOCIETY BETWEEN LIBERALISM AND REBOLSHEVIZATION}

\section{Summary}

This paper analyzes the tides of certain liberal tendencies in the Macedonian society during the period of socialist Yugoslavia. The analysis is set in the context of political freedoms, freedom of work and opportunities for different interpretations of the social conditions in that time. In this framework some typical examples of a personal nature are suggested through which the trends of Bolshevism and liberalism in the country were violated.

Keywords: BOLSHEVISM, DOGMATISM, LIBERALIZM, SOC-REALIZAM, COMMUNISM, DEMOCRACY. 